\title{
Quantification of the sedimentation and accumulation of Cr in Jiaozhou Bay
}

\author{
Dongfang Yang ${ }^{1,2, a}$, Zhenqing Miao ${ }^{3, \text { b,c }}$, Linzhen Wei ${ }^{1}$, Ming Feng ${ }^{1}$ and Mei Chen ${ }^{1}$ \\ ${ }^{1}$ School of International Economics, Shaanxi Institute of International Trade \& commerce, Xi'an 712046, \\ China; \\ ${ }^{2}$ North China Sea Environmental Monitoring Center, SOA, Qingdao 266033, China; \\ ${ }^{3}$ College of Fisheries, Zhejiang Ocean University, Zhoushan, 316022, China. \\ adfyang_dfyang@126.com, b corresponding author, cmzq@zjou.edu.cn
}

Keywords: Cr; Sedimentation; Accumulation; Quantification; Jiaozhou Bay.

\begin{abstract}
Sedimentation and accumulation are important migration processes of pollutants in marine bay, and the quantification of these processes are essential to pollution control. Jiaozhou Bay is a semi-closed bay located in Shandong Province, China. Based on investigation data on Cr during 1979-1983, this paper analyzed the vertical variations of $\mathrm{Cr}$, and quantified the sedimentation and accumulation of $\mathrm{Cr}$ in Jiaozhou Bay. Results showed that $\mathrm{Cr}$ contents in bottom waters were consist with which in surface waters, and the differences between surface and bottom waters were small. The absolute sedimentation amount, relative sedimentation amount, absolute accumulation amount and relative accumulation amount of Cr were 0.30-2.18 $\mu \mathrm{g} \mathrm{L}^{-1}, 62.5 \%-92.8 \%, 0.37-1.84 \mu \mathrm{g} \mathrm{L}^{-1}$ and 681.4\%-1336.3\%, respectively. The sedimentation and of $\mathrm{Cr}$ and the accumulation of $\mathrm{Cr}$ in bottom waters were notable.
\end{abstract}

\section{Introduction}

Many marine bays in the whole word have been polluted by various pollutants due to the rapid increase of industry. $\mathrm{Cr}$ is one of the widely used heavy metal elements and $\mathrm{Cr}$ pollution is one of the critical environmental issues [1-4]. Sedimentation and accumulation are important migration processes of pollutants in marine bays, and the quantification of these processes are essential to pollution control. However, there were still few studies about the quantification of sedimentation and accumulation of pollutants in marine bays.

Jiaozhou Bay is a semi-closed bay located in Shandong Province, eastern China, and has been polluted by various pollutants include $\mathrm{Cr}$ [5-9]. Based on investigation data on Cr during 1979-1983, this paper analyzed the vertical variations of $\mathrm{Cr}$, and quantified the sedimentation and accumulation of $\mathrm{Cr}$ in Jiaozhou Bay. Results found that the annual average relative sedimentation amount and relative accumulation amount were $84.2 \%$ and $1059.2 \%$, respectively. The sedimentation and of $\mathrm{Cr}$ and the accumulation of $\mathrm{Cr}$ in bottom waters were notable. These results were essential to pollution control and environmental remediation.

\section{Materials and method}

Jiaozhou Bay $\left(35^{\circ} 55^{\prime}-36^{\circ} 18^{\prime} \mathrm{N}, 120^{\circ} 04^{\prime}-120^{\circ} 23^{\prime} \mathrm{E}\right)$ is located in the south of Shandong Peninsula, eastern China. The area, bay mouth width and average water depth and average water depth are $390 \mathrm{~km}^{2}, 2.5 \mathrm{~km}$ and $7.0 \mathrm{~m}$, respectively (Fig. 1). This bay is surrounding by cities of Qingdao, Jiaozhou and Jiaonan in the east, north and south, respectively. The bay mouth is located in the south of the bay, and is connected with the Yellow Sea. There are more than ten inflow rivers such as Loushan River, Licun River and Haibo River [10-11].

The investigation on $\mathrm{Cr}$ in surface waters in Jiaozhou Bay was conducted by North China Sea Environmental Monitoring Center. The investigation times were in August 1979, April and August 1981, April, July and October 1982, and May, September and October 1983, respectively [3-9], and 
the sampling sites were showed in Fig. 1. The investigation and measurement of Cr were following by National Specification for Marine Monitoring [12].

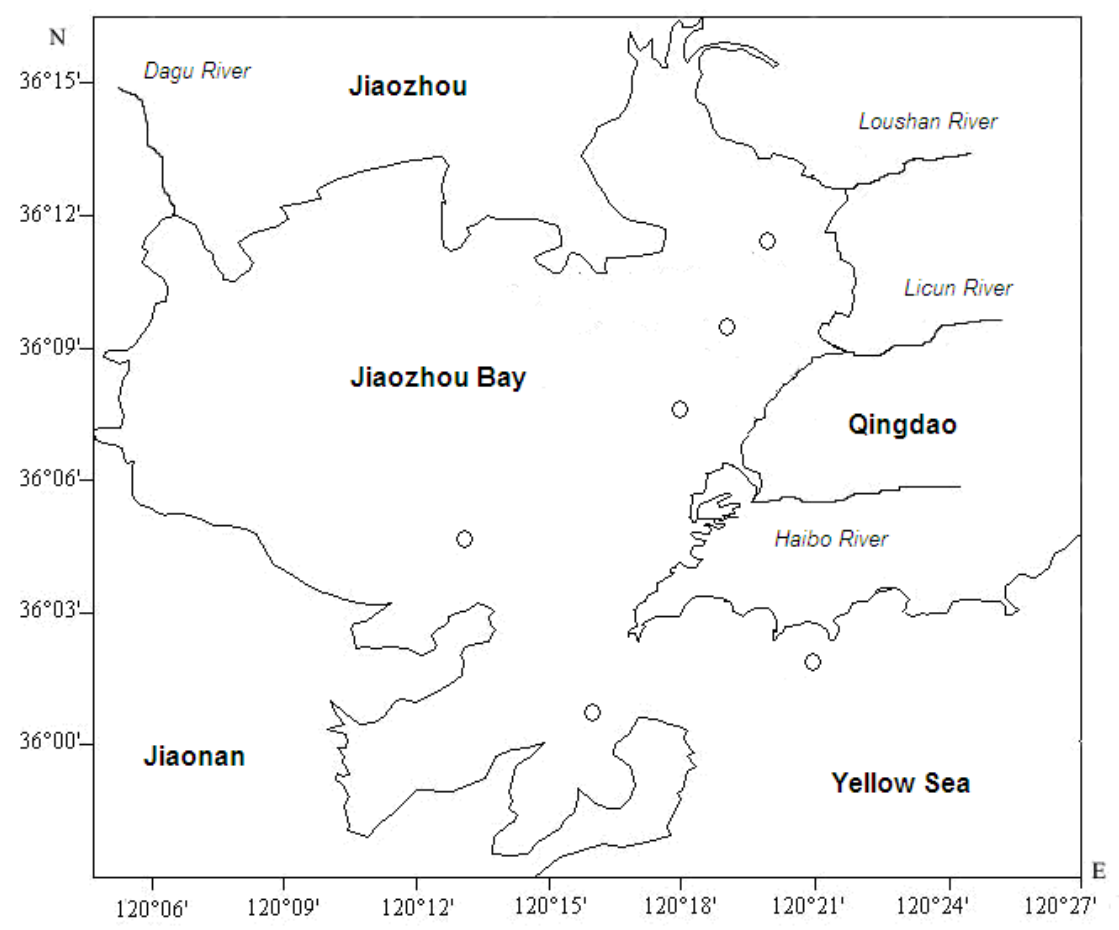

Fig.1 Geographic location and sampling sites of Jiaozhou Bay

\section{Results and discussion}

\subsection{Vertical variations of $\mathrm{Cr}$.}

Based on the climate in study area, April, May and June are spring, July, August and September are summer, and October, November and December are autumn, respectively. In order to reveal the vertical variations of $\mathrm{Cr}$, we calculated the ranges of $\mathrm{Cr}$ in surface and bottom waters, and the differences of $\mathrm{Cr}$ contents between surface and bottom waters (Table 1). As listed in Table 1, Cr contents in bottom waters were relative low in case of $\mathrm{Cr}$ contents in surface waters were relative low, and $\mathrm{Cr}$ contents in bottom waters were relative high in case of $\mathrm{Cr}$ contents in surface waters were relative high. In generally, $\mathrm{Cr}$ contents in bottom waters were consist with which in surface waters, and the differences between surface and bottom waters were small, never no matter in different years or seasons. Hence, it could be found that the sedimentation and of $\mathrm{Cr}$ and the accumulation of $\mathrm{Cr}$ in bottom waters were notable.

\subsection{Sedimentation and accumulation of $\mathrm{Cr}$.}

In according to the $\mathrm{Cr}$ in surface and bottom waters and the differences between surface and bottom waters (Table 1), we could find that $\mathrm{Cr}$ contents in surface and bottom waters were tending to be consisting. The major reason was sedimentation and accumulation. The sedimentation amount of $\mathrm{Cr}$ was large in case of $\mathrm{Cr}$ contents in surface waters were high, yet would be small in case of $\mathrm{Cr}$ contents in surface waters were low, resulting in the consistency of $\mathrm{Cr}$ contents in surface and bottom waters. Based on $\mathrm{Cr}$ contents in surface and bottom waters, the absolute sedimentation amount, relative sedimentation amount, absolute accumulation amount and relative accumulation amount of $\mathrm{Cr}$ were calculated as $0.30-2.18 \mu \mathrm{g} \mathrm{L} \mathrm{L}^{-1}, 62.5 \%-92.8 \%, 0.37-1.84 \mu \mathrm{g} \mathrm{L} \mathrm{L}^{-1}$ and 681.4\%-1336.3\%, respectively (Table 2). It could be seen from Table 2 that the absolute and relative sedimentation and accumulation amounts of $\mathrm{Cr}$ in Jiaozhou Bay were different in different years. The annual average relative sedimentation amount and relative accumulation amount were $84.2 \%$ 
and $1059.2 \%$, respectively, indicated that the sedimentation and of $\mathrm{Cr}$ and the accumulation of $\mathrm{Cr}$ in bottom waters were notable.

Table $1 \mathrm{Cr}$ in surface and bottom waters and the differences between surface and bottom waters

\begin{tabular}{|c|c|c|c|c|}
\hline \multirow{2}{*}{ Year } & \multirow{2}{*}{ Season } & \multicolumn{2}{|c|}{ Cr content $/ \mu \mathrm{g} \mathrm{L}^{-1}$} & \multirow{2}{*}{ Difference/ $\mu \mathrm{g} \mathrm{L}^{-1}$} \\
\hline & & Surface waters & Bottom waters & \\
\hline \multirow{3}{*}{1979} & Spring & 0.10 to 1.40 & 0.03 to 0.40 & -0.86 to 0.25 \\
\hline & Summer & & & \\
\hline & Autumn & & & \\
\hline \multirow{3}{*}{1981} & Spring & & & \\
\hline & Summer & 0.18 to 0.48 & 0.14 to 1.42 & -0.86 to 0.25 \\
\hline & Autumn & & & \\
\hline \multirow{3}{*}{1982} & Spring & 0.81 to 2.11 & 0.81 to 0.95 & -0.12 to 0.51 \\
\hline & Summer & 1.02 to 2.42 & 1.20 to 2.11 & -1.09 to 0.17 \\
\hline & Autumn & 0.24 to 1.35 & 0.27 to 0.51 & -0.07 to 0.28 \\
\hline \multirow{3}{*}{1983} & Spring & 0.13 to 0.65 & 0.11 to 1.08 & -0.86 to 0.25 \\
\hline & Summer & 0.70 to 1.17 & 0.46 to 1.17 & -0.42 to 0.44 \\
\hline & Autumn & 0.44 to 1.56 & 0.63 to 1.58 & -0.21 to 0.66 \\
\hline
\end{tabular}

Table $2 \mathrm{Cr}$ in surface and bottom waters and the differences between surface and bottom waters $/ \mu \mathrm{g} \mathrm{L}^{-1}$

\begin{tabular}{|c|c|c|c|c|c|}
\hline Year & 1979 & 1981 & 1982 & 1983 & Average \\
\hline $\begin{array}{l}\text { Absolute } \\
\text { sedimentation } \\
\text { amount } / \mu \mathrm{g} \mathrm{L}^{-1}\end{array}$ & 1.30 & 0.30 & 2.18 & 1.43 & 1.30 \\
\hline $\begin{array}{l}\text { Relative } \\
\text { sedimentation } \\
\text { amount/\% }\end{array}$ & 92.8 & 62.5 & 90.0 & 91.6 & 84.2 \\
\hline $\begin{array}{l}\text { Absolute } \\
\text { accumulation } \\
\text { amount } / \mu \mathrm{g} \mathrm{L}^{-1}\end{array}$ & 0.37 & 1.38 & 1.84 & 1.47 & 1.27 \\
\hline $\begin{array}{l}\text { Relative } \\
\text { accumulation } \\
\text { amount } / \%\end{array}$ & 1233.3 & 985.7 & 681.4 & 1336.3 & 1059.2 \\
\hline
\end{tabular}

\section{Conclusions}

Cr contents in bottom waters were consist with which in surface waters, and the differences between surface and bottom waters were small, never no matter in different years or seasons. The sedimentation amount of $\mathrm{Cr}$ was large in case of $\mathrm{Cr}$ contents in surface waters were high, yet would be small in case of $\mathrm{Cr}$ contents in surface waters were low, resulting in the consistency of $\mathrm{Cr}$ contents in surface and bottom waters. The absolute sedimentation amount, relative sedimentation amount, absolute accumulation amount and relative accumulation amount of $\mathrm{Cr}$ were calculated as 0.30-2.18 $\mu \mathrm{g} \mathrm{L}^{-1}, 62.5 \%-92.8 \%, 0.37-1.84 \mu \mathrm{g} \mathrm{L} \mathrm{L}^{-1}$ and 681.4\%-1336.3\%, respectively, indicated that the sedimentation and of $\mathrm{Cr}$ and the accumulation of $\mathrm{Cr}$ in bottom waters were notable. The results were essential to pollution control and environmental remediation.

\section{Acknowledgement}

This research was sponsored by Doctoral Degree Construction Library of Guizhou Nationalities University, Education Ministry's New Century Excellent Talents Supporting Plan (NCET-12-0659), the China National Natural Science Foundation (31560107), Major Project of Science and Technology of Guizhou Provincial ([2004]6007-01), Guizhou R\&D Program for Social Development ([2014] 3036) and Research Projects of Guizhou Nationalities University ([2014]02), Research Projects of Guizhou Province Ministry of Education (KY [2014] 266), Research Projects 
of Guizhou Province Ministry of Science and Technology (LH [2014] 7376).

\section{References}

[1] Yang DF and Miao ZQ: Marine Bay Ecology (I): Beijing, Ocean Precess, (2010), p. 1-320. (in Chinese)

[2] Yang DF and Gao ZH: Marine Bay Ecology (II): Beijing, Ocean Precess, (2010), p. 1-330. (in Chinese)

[3] Yang DF, Gao ZH, Sun JY, et al.: Coastal Enginerring, Vol. 27 (2008), p. 48- 53. (in Chinese with English Abstract)

[4] Yang DF, Wang FY, He HZ, et al.: Applied Mechanics and Materials, Vol. 675-677 (2014), p. 329-331.

[5] Yang DF, Zhu SX, Wang FY, et al.: Applied Mechanics and Materials, Vol.644-650 (2014), p. 5325-5328.

[6] Yang DF, Zhu SX, Wang FY, et al.: 2014 IEEE workshop on advanced research and technology industry applications. Part D, Vol. (2014), p. 1018-1020.

[7] Yang DF, Zhu SX, Sun ZH, et al.: Advances in Engineering research, Vol. (2015), p. 1375-1378.

[8] Yang DF, Zhu SX, Yang XQ, et al.: Advances in Engineering research, Vol. (2015), p. 1383-1385.

[9] Yang DF, Wang FY, Sun ZH, et al.: Materials Engineering and Information Technology Application, Vol. (2015), p.562-564.

[10] Yang DF, Chen Y, Gao ZH, et al.: Chinese Journal of Oceanology and Limnology, Vol. 23 (2005), p. 72-90. (in Chinese with English Abstract)

[11]Yang DF, Wang F, Gao ZH, et al.: Marine Science, Vol. 28 (2004), p.71-74. (in Chinese with English Abstract)

[12] State Ocean Administration. The specification for marine monitoring: Beijing, Ocean Precess, (1991). (in Chinese)

[13]Yang DF, Wang FY, He HZ, et al.: Proceedings of the 2015 international symposium on computers and informatics, 2015, p. 2655-2660.

[14] Yang DF, Wang FY, Zhao XL, et al.: Sustainable Energy and Enviroment Protection, Vol. (2015), p. 191-195.

[15] Yang DF, Wang FY, Yang XQ, et al.: Advances in Computer Science Research, Vol. (2015), p. 198-204.

[16]Yang DF, Miao ZQ, Xu HZ, et al.: Ocean Development and Management, Vol. 30 (2013), p. 46-50.

[17] Yang DF, Wang FY, Zhu SX, et al.: Applied Mechanics and Materials, Vols.651-653(2014), p. 1415-1418. 